\title{
PEMANFAATAN HIJAUAN RAWA TERMODIFIKASI SEBAGAI PAKAN LENGKAP GRANULE TERHADAP KARKAS DAN DAGING KAMBING LOKAL
}

\section{UTILIZATION OF MODIFIED SWAMP FORAGE AS COMPLETE GRANULE FEED ON CARCASSES AND LOCAL GOAT MEAT}

\author{
MI Zakir1a dan A Jaelani \\ ${ }^{1}$ Program Studi Peternakan Fakultas Pertanian Universitas Islam Kalimantan Muhammad Arsyad \\ Al Banjari, Jl. Adhyaksa No. 2 kayu tangi Banjarmasin \\ aKorespondensi: Achmad Jaelani, E-mail: jaelaniborneo@gmail.com
}

(Received: 28-09-2020; Accepted: 11-10-2020)

\begin{abstract}
Forage swamps generally have crude fiber content and tannin content which is quite high. Unlike the case with legumes which are high in protein content but crude fiber content, and tannins that are not too high compared to swamp forages. The presence of tannin in swamp forage, has an impact on palatability, digestibility and biological value of feed. In such a situation, modification of swamp forages with tree legumes is a promising alternative source of feed for goats. Protein in small ruminant animals is generally degraded in the rumen before reaching the abomasum, where absorption of nutrients occurs. As a result, protein digestibility will be reduced because it is damaged during the journey to the abomasum, so there needs to be modification so that protein damage to the rumen can be reduced. One way is to create a protein protector that is able to protect protein by using tannin which is quite abundant in swamp forages. In addition to functioning as a protein protector, tannin is also useful as an anthelmintic agent (anti-parasite) in goats, so that it will reduce the occurrence of worm disease in goats so that it will reduce the use of worm parasitic drugs which will have an impact on goat performance.The specific objectives of this study were to analyze the ability of a combination of swamp forage with modified legume as a complete feed granule with different tannin content on the quality of local carcass and goat meat. Trial feeding was carried out on 12 male local goats aged 1.5-2 years, body weight $33-35 \mathrm{~kg}$. At this stage a modified swamp and legume forage in the form of granules was modified as a complete feed on the performance of local meat-producing goats. Parameters measured included: Carcass quality, physical and organoleptic quality of meat.The results showed that the application of swamp forage and indigofera legume on male goats affected the cut weight and carcass percentage. Giving a combination of swamp forage with indigofera legume with different tannin content affects the physical properties of goat meat which includes cooking losses, water holding capacity, but does not affect the tenderness of meat, and $\mathrm{pH}$.
\end{abstract}

Keywords: swamp forage, carcass and meat, local goat

\section{ABSTRAK}

Hijauan rawa umumnya memiliki kandungan serat kasar dan kandungan tannin yang cukup tinggi. Berbeda halnya dengan legume yang tinggi kandungan protein namun kandungan serat kasar, dan tannin yang tidak terlalu tinggi dibanding hijauan rawa. Keberadaan tannin pada hijauan rawa, berdampak pada palatabilitas, kecernaan dan nilai biologis pakan. Dalam situasi seperti ini, modifikasi hijauan rawa dengan leguminosa pohon merupakan alternatif sumber pakan yang menjanjikan bagi ternak kambing. Protein pada ternak ruminansia kecil umumnya terdegradasi di rumen sebelum mencapai abomasum, tempat terjadinya penyerapan zat-zat nutrisi. Akibatnya kecernaan protein akan berkurang karena rusak selama dalam perjalanan menuju abomasum, sehingga perlu adanya modifikasi agar kerusakan protein pada rumen bisa dikurangi. Salah satu cara adalah dengan menciptakan protektor protein yang mampu melindungi protein dengan menggunakan tannin yang cukup banyak terdapat pada hijauan rawa. Selain itu selain berfungsi sebagi protektor protein, tannin juga bermanfaat sebagai agent anthelmintika (anti parasite) pada kambing, sehingga akan mengurangi terjadinya penyakit cacing pada kambing sehingga akan menurunkan penggunaan obat-obatan parasit 
cacing yang akan berdampak pada kinerja kambing. Tujuan khusus penelitian ini adalah : menganalisis kemampuan kombinasi hijauan rawa dengan legume termodifikasi sebagai pakan komplit granul dengan kandungan tannin yang berbeda terhadap kualitas karkas dan daging kambing lokal Pada penelitian ini dilakukan feeding Trial dilakukan pada 12 ekor kambing lokal jantan umur 1,5-2 tahun, bobot badan 33-35 kg. Pada Tahap ini dilakukan modifikasi pakan hijauan rawa dan legume dalam bentuk granule sebagai pakan komplet erhadap kinerja kambing lokal penghasil daging. Parameter yang diukur meliputi : Kualitas karkas, kualitas fisik dan organoleptik daging. Hasil penelitian menunjukan bahwa Pemberikan hijauan rawa dan legume indigofera pada kambing jantan berpengaruh terhadap bobot potong dan persentase karkas. Pemberian kombinasi hijauan rawa dengan legume indigofera dengan kandungan tannin yang berbeda berpengaruh terhadap sifat fisik daging kambing yang meliputi susut masak, daya ikat air, namun tidak berpengaruh terhadap kempukan daging, dan $\mathrm{pH}$.

Kata Kunci: hijauan rawa, karkas dan daging, kambing lokal

MI Zakir, A jaelani. 2020. Pemanfaatan Hijauan Rawa Termodifikasi Sebagai Pakan Lengkap Granule Terhadap Karkas dan Daging Kambing Lokal. Jurnal Peternakan Nusantara 6(2): 97-102

\section{PENDAHULUAN}

Dalam manajemen pemeliharan, peternak seringkali tidak memperhatikan kesehatan ternaknya sehingga seringkali ternak kambingnya terjangkit penyakit yang disebabkan parasite/cacing. Adapun cacing yang sering menyerang kambing adalah Haemonchus contortus yang menghisap darah dengan menggigit saluran pencernaan dan akibatnya akan menurunkan kinerja kambing hingga 30\%.

Upaya pemanfaatan sumber pakan lokal menjadi sangat penting untuk meningkatkan efisiensi pakan. Salah satu sumber hijauan pakan yang banyak di daerah pasang surut/rawa dan belum banyak dimanfaatkan sebagai bahan pakan ternak kambing adalah hijauan rawa. Keberadaan hijauan rawa lebih sering dianggap sebagai gulma karena dapat menyebabkan pendangkalan serta menyebabkan pengurangan/ penguapan air dan unsur hara yang besar.

Produksi bahan kering hijauan rawa dengan sistem panen 2 - 3 kali seminggu menghasilkan 44 ton/ha/th (leng et al, 1994) namun hijauan rawa umumnya tinggi akan serat kasar dan tannin (lebih dari 2\%). Tanin dalam pakan ternak dapat berfungsi sebagai anti parasite/cacing (anthelmintika) dan akan bereaksi langsung dengan cacing dewasa sehingga akan menyebabkan cacing distress, mengurangi faecal egg, menekan perkembangbiakan larva, menginduksi penghambatan fecunditas cacing sehingga telur cacing pada ternak kambing yang terinfeksi menurun.
Disamping itu Tannin juga akan berikatan dengan protein rumen sehingga menyebabkan protein terproteksi. Protein pada ternak ruminansia kecil umumnya terdegradasi di rumen sebelum mencapai abomasum, tempat terjadinya penyerapan zat-zat nutrisi. Akibatnya kecernaan protein akan berkurang karena rusak selama dalam perjalanan menuju abomasum, sehingga perlu adanya modifikasi agar kerusakan protein pada rumen bisa dikurangi.

Penggunaan kombinasi rumput rawa dan legume yang tinggi kandungan protein sebagai sumber pakan utama ternak kambing dapat memenuhi kebutuhan nutrisi untuk produkstivitas tinggi (Fujisaka et al., 2000), mengingat kandungan protein rumput rawa tropis relatif rendah berkisar antara 4-9\%, sedangkan kebutuhan protein ransum kambing mencapai 14\%, sehingga perlu adanya kombinasi pemberiannya dengan legume. Salah satu cara adalah dengan menciptakan pelindung (protector) protein yang mampu melindungi protein dengan menggunakan tannin yang cukup banyak terdapat pada hijauan rawa.

Tujuan Penelitian adalah untuk menganalisis secara in vivo kemampuan hijauan rawa termodifikasi, sebagai pakan lengkap granule terhadap kualitas karkas dan daging kambing lokal.

\section{MATERI DAN METODE}

\section{Materi}

Penelitian aplikasi pakan akan dilakukan selama dua bulan, bertempat di kandang ternak 
Laboratorium Lapang Faperta UNISKA Banjarmasin.

Bahan yang digunakan adalah kambing lokal umur satu tahun sebanyak 12 ekor, Hijauan rawa, Legume Indigofera sp., dedak padi dan ampas tahu, ransum disusun isokalori dan isonitrogen., mesin pencacah halus rumput, mesin granule, sprayer

\section{Perlakuan}

Rancangan percobaan yang digunakan adalah rancangan acak kelompok dengan 3 perlakuan dengan 4 blok ulangan, dimana setiap ulangan terdiri dari 1 ekor kambing pedaging, sehingga jumlah kambing adalah 12 ekor

$\mathrm{R} 1=$ Modifikasi Hijauan rawa dengan kandungan tannin rendah + legume Indigofera

$\mathrm{R} 2$ = Modifikasi Hijauan rawa dengan kandungan tannin sedang + legum Indigofera

R3 = Modifikasi Hijauan rawa dengan kandungan tannin tinggi + legume indigofera

\section{Peubah yang Diamati}

1. Kualitas karkas (bobot karkas dan prosentase karkas)

2. Kualitas daging (fisik yang meliputi : $\mathrm{pH}$, daya ikat air, ssut masak. uji organoleptik meliputi : keempukan, warna).

\section{Analisis Data}

Data yang diperoleh dianalisis dengan sidik ragam (ANOVA) dan jika perlakuan berpengaruh nyata terhadap peubah yang diamati maka analisis dilanjutkan dengan uji lanjut jarak ganda Duncan

\section{Prosedur Pelaksanaan}

Semua ternak kambing ditempatkan pada kandang individu tipe panggung sebanyak 12 petak untuk lebih memudahkan mengamati. Penempatan ternak kambing dalam petak kandang dilakukan secara acak untuk mendapatkan perlakuan. Sebelum dilakukan penelitian ternak diberikan waktu untuk beradaptasi terhadap lingkungan dan pakannya selama 1 minggu (7 hari) dengan semua ransum percobaan. Sebelumnya penelitian berlangsung semua ternak kambing ditimbang bobot badan untuk mendapatkan data bobot badan awal. Dilakukan pencukuran bulu, pemotongan kuku dan memandikan ternak yang dicampur dengan azuntol.

Waktu pemberian pakan pada jam 07.00 dan 1200 siang. Sisa pakan perlakuan ditimbang keesokan harinya untuk mengetahui konsumsi dari ternak tersebut. Pemberian air minum secara terus menerus di kandang secara adlibitum.

Penimbangan bobot badan selama penelitian dilakukan setiap minggu yaitu pagi hari sebelum pemberian pakan dan air minum pada saat akan mencapai bobot akhir untuk dipotong. Penimbangan bobot badan dilakukan setiap hari selama 3 hari berturut-turut.

Pertambahan bobot badan dicatat. Setiap minggu yaitu dengan menghitung selisih bobot badan pada masa awal dengan akhir masa penimbangan tiap minggu. Persiapan sampel dimulai dari pemeriksaan kondisi kesehatan ternak dan persiapan pemotongan ternak. Ternak dipuasakan selama 12 jam sebelum dipotong.

Prosedur pemotongan ternak dilakukan menurut Syariat Islam. Posisi ternak menghadap ke kiblat, membaca basmalah serta penyembelihan dilakukan dengan memotong saluran oesophagus, memutuskan urat nadi (arteri carotis dan vena jugularis) dan trachea. Setelah ternak disembelih dan dilakukan pengeluaran darah, dilakukan pemisahan bagian kepala, ekor, dan ke-empat pergelangan kaki.

Ternak digantung pada posisi bagian kepala menghadap ke bawah dan dilanjutkan dengan dressing yang terdiri dari pengulitan dan pengeluaran jeroan sehingga diperoleh karkas hangat. Selanjutnya karkas ditimbang dan dibungkus dengan plastik, diletakkan pada permukaan meja yang bersih dan dibiarkan untuk mengalami proses rigormortis selama +60 menit pada suhu kamar. Setelah rigormortis selesai, dilakukan pemotongan dan penimbangan paha belakang.

Acuan pemotongan paha belakang dilakukan menurut Romans \& Ziegler (1974). Bagian paha belakang selanjutnya dipisahkan dari karkas, dibungkus dengan plastik wrapping kemudian dimasukkan ke dalam wadah plastik dan dibawa menuju laboratorium. Selanjutnya dilakukan deboning secara manual. Daging paha yang sudah dipisahkan dari tulangnya, selanjutnya dipotong dengan ukuran $+2 \times 2 \times 2$ $\mathrm{cm}$ dan dikemas dengan alumunium foil yang 
sudah dilaminasi, divakum dan dibekukan pada suhu -23 oC hingga dilakukan analisis.

\section{HASIL DAN PEMBAHASAN}

Dari hasil penelitian awal diperoleh kandungan nutrisi pakan yang diberikan disajikan pada Tabel 1.

Tabel 1 Komposisi Karkas kambing penelitian

\begin{tabular}{|c|c|c|c|c|}
\hline \multirow{2}{*}{ No } & \multirow{2}{*}{$\begin{array}{c}\text { Parameter } \\
\text { Uji }\end{array}$} & \multicolumn{3}{|c|}{ Perlakuan } \\
\hline & & $\mathrm{R} 1$ & $\mathrm{R} 2$ & R3 \\
\hline 1 & $\begin{array}{l}\text { Bobot } \\
\text { Potong }(\mathrm{kg})\end{array}$ & $35,22 \mathrm{a}$ & $36,57 \mathrm{a}$ & $34,83 \mathrm{a}$ \\
\hline 2 & $\begin{array}{l}\text { Bobot } \\
\text { karkas (kg) }\end{array}$ & $15,96 \mathrm{a}$ & $16,39 a$ & $13,82 \mathrm{~b}$ \\
\hline 3 & $\begin{array}{l}\text { Persentase } \\
\text { karkas }(\%)\end{array}$ & $45,36 \mathrm{a}$ & $44,84 \mathrm{a}$ & $39,67 \mathrm{~b}$ \\
\hline
\end{tabular}

Berdasarkan hasil penelitian diperoleh bahwa persentase bobot potong tidak menunjukan adanya perbedaan diantara ke 3 perlakuan. Namun bobot potong tertinggi diperoleh pada perlakuan R2 (36,57 kg), dusul perlakuan R1 $(35,22 \mathrm{~kg})$ dan R3 $(34,83 \mathrm{~kg})$. Terjadi trend penurunan bobot potong sejalan dengan kandungan tannin dalam pakan kombinasi hijauan rawa dengan legume indigofera.

Berdasarkan nilai bobot karkas dan persentasi karkas menunjukan perbedaan antara perlakuan R1 dan R2 dengan perlakuan R3. Kambing diduga masih bias mentoleris keberadaan tannin yang jumlahnya sedang, sehingga tidak memberikan dampak buruk terhadap bobot karkas dan persentase karkas. Namun jika kandungan tannin dalam pakan tinggi maka terlihat jelas dari penampilan bobot karkas dan persentase bobot karkas yang semakin menurun.

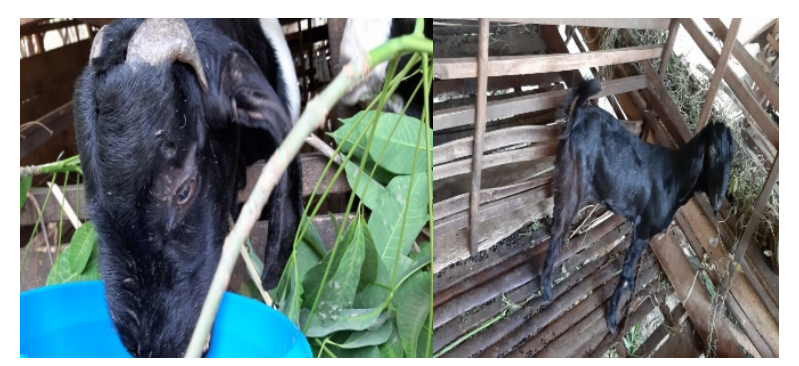

Gambar 1 Kambing jantan lokal yang digunakan dalam penelitian
Umumnya hasil utama yang diharapkan dari pemeliharaan kambing adalah dagingnya. Selain rasanya yang lezat, daging memiliki kandungan gizi yang lengkap. Romans et al. (1994) menyatakan bahwa kualitas daging dapat ditentukan berdasarkan perubahan komponenkomponen kimianya seperti kadar air, protein, lemak dan abu. Sifat kimia daging bervariasi tergantung spesies ternak, umur, jenis kelamin, pakan serta lokasi dan fungsi bagian-bagian otot dalam tubuh. Menurut Mahmud et al. (2009), komposisi zat gizi daging kambing per $100 \mathrm{~g}$ adalah air 70,3 g, protein 16,6 g, lemak 9,2 g, dan abu 3,9 g.

Tabel 2 Kualitas Fisik daging kambing perlakuan

\begin{tabular}{clccc}
\hline \multirow{2}{*}{ No } & \multirow{2}{*}{\begin{tabular}{c} 
Parameter \\
\cline { 3 - 5 }
\end{tabular}} & \multicolumn{3}{c}{ Perlakuan } \\
\cline { 3 - 5 } 1 & Kadar Air & R1 & R2 & R3 \\
\hline & $(\%)$ & 78,24 & 77,29 & 76,82 \\
2 & pH & 5,07 & 5,11 & 5,08 \\
3 & Susut & 43,27 & 46,16 & 40,53 \\
& masak (\%) & & & \\
4 & $\begin{array}{l}\text { Daya Ikat } \\
\text { Air (\%) }\end{array}$ & 21,54 & 29,18 & 24,72 \\
\hline
\end{tabular}

\section{Kadar Air Daging}

Kadar air daging hasil penelitian ini menunjukan perbedaan yang nyata $(P<0,05)$ diantara ketiga perlakuan. Rata-rata kadar air daging kambing hasil penelitian ini adalah $77,85 \%$. Nilai bahan kering tertinggi diperoleh pada perlakuan R2, selanjutnya R3 dan R1. Hal ini menunjukan bahwa pada pahan kombinasi hijauan rawa dengan indigofera yang memiliki kandungan tannin yang lebih tinggi, nilai DM nya lebih tinggi atau kandungan airnya lebih rendah pada daging kambingnya. Faktor-faktor yang mempengaruhi kadar air daging adalah spesies ternak, umur, jenis kelamin, pakan serta lokasi dan fungsi bagian-bagian otot dalam tubuh (Romans et al., 1994). Berbedanya kadar air daging kambing pada penelitian ini kemungkinan karena kambing yang digunakan sudah melewati pertumbuhan pasca pubertas. Beserra et al. 2004 menyatakan bahwa peningkatan umur potong juga dapat meningkatkan kadar protein, lemak dan abu pada daging kambing asal Pakistan (Arain et al. 2010). Jibir et al. (2010) menunjukkan bahwa umur potong tidak mempengaruhi kadar air, protein, lemak dan abu daging kambing Nigeria jenis Sahel dan Sakoto Red. Di Indonesia masih sedikit informasi mengenai kajian umur potong 
terhadap profil karkas dan komposisi kimia yang ditinjau dari kadar kolesterol, komposisi asam amino dan asam lemak yang berasal dari kambing

\section{pH Daging}

Pada hasil pengujian tidak terjadi perbedaan yang mencolok. Hal tersebut kemungkinan daging masih segar sehingga pHnya pun masih termasuk normal. Hampir semua bakteri tumbuh secara optimal pada $\mathrm{pH}$ sekitar 7 dan tidak akan tumbuh persis dibawah $\mathrm{pH} 4$ atau diatas 9, tetapi $\mathrm{pH}$ untuk pertumbuhan optimal ditentukan oleh kerja stimulan dari berbagai variabel lain di luar faktor keasaman itu sendiri (Lawrie, 1979). Faktor lain yang memungkinkan menjadi penyebab $\mathrm{pH}$ daging tidak jauh berbeda adalah ketidakakuratan data akibat alat dan ketelitian.

\section{Daya Ikat Air}

Hasil pengujian daya mengikat air, perlakuan R2 memiliki kemampuan daya mengikat air lebih besar dari pada Perlakuan lainnya. Hasil ini kurang sesuai dengan literatur akibat adanya tannin yang mengikat protein pakan sehingga protein mengalami kerusakan sehingga kemampuan protein daging dalam mengikat air bebas akan menurun. Hal ini sesuai dengan pendapat Bhattacharya (1988) yang mengatakan bahwa proses pengikatan protein dapat meningkatkan kerusakan protein daging, sehingga daya ikat air terhadap protein daging akan semakin lemah, yang akan menyebabkan nilai daya ikat air menurun. Penurunan nilai daya ikat air oleh protein daging terjadi kegagalan serabut otot menyerap kembali semua air yang mengalami translokasi atau keluar pada saat penyimpanan (Bratzler et al., 1977 dan Lawrie, 1979). Tapi jika dilihat dari nilai $\mathrm{pH}$ hasil ini sesuai, karena semakin tinggi nilai $\mathrm{pH}$ maka daya ikat air akan semakin tinggi.
Hasil pengujian susut masak daging menunjukkan bahwa daya mengikat air daging Perlakuan R2 $(46,16 \%)$ lebih besar dari pada nilai susut masak daging Perlakuan R1 $(43,27 \%)$ maupun R3 (40,53\%). Hal ini dapat terjadi karena daya mengikat air pada perlakuan dengan tannin tinggi kemampuan mengikat protein juga tinggi, sehingga berdampak pada nilai susut masak.. Semakin tinggi daya mengikat air daging semakin sedikit cairan yang keluar dari daging tersebut. Hal ini mengakibatkan massa dari daging yang berkurang juga sedikit. Penurunan nilai daya mengikat air juga dapat meningkatkan nilai susut masak (Jamhari, 2000).

\section{Uji Organoleptik \\ Keempukan}

Hasil pengujian pada nilai keempukan daging menunjukkan bahwa nilai keempukan daging Perlakuan R1, R2 dan R3 tidak menunjukan perbedaan. Nilai ini berarti bahawa kebedaan tannin dalam pakan kambing tidak berpengaruh terhadap keempukan daging. Hal ini dapat terjadi karena daya ikat air lebih tinggi sehingga air beratnya hanya sedikit yang menyusut dan keempukannyapun lebih baik.

\section{Warna}

Dilihat dari warna secara inderawi, bahwa perlakuan R1 lebih cerah dibandingkan dengan perlakuan R2 maupunR3. Hal ii diduga bahwa keberadaan tannin pada pakan yang mengikat protein, mempengaruhi warna daging karena umumnya tannin berwarna gelap dan pahit. Perbedaan warna ini akan lebih jelas lagi jika menggunakan alat yang lebih sensitive seoerti Kromatometer.

\section{Susut Masak}




\section{KESIMPULAN}

\section{Kesimpulan}

Pemberikan hijauan rawa dan legume indigofera pada kambing jantan berpengaruh terhadap bobot potong dan persentase karkas.

Pemberian kombinasi hijauan rawa dengan legume indigofera dengan kandungan tannin yang berbeda berpengaruh terhadap sifat fisik daging kambing yang meliputi susut masak, daya ikat air, namun tidak berpengaruh terhadap kempukan daging, dan $\mathrm{pH}$.

\section{DAFTAR PUSTAKA}

Association of Official Analytical Chemist (AOAC). 1999. Official Methods of Analysis. Ed ke-16.Washington: AOAC International.

Badjoeri M, Lukman 2002. Pemanfaatan tumbuhan kumpai dari danau semayang sebagai pakan sapi. Jurnal tropic Animal agriculture. 27 (2) : 125-133.

Badan Pusat Statistik Direktorat Jendral Tanaman Pangan. 2010. Luas lahan rawa di Indonesia, Departemen Pertanian. Jakarta.

Badan Pusat Statistik .2011. Kalimantan Selatan Dalam angka. BPS Kalsel

Biren Shah, Avinash Seth. Textbook of Pharmacognosy And Phytochemistry. Elsevier Health Sciences : Amsterdam. 2012. P384.

Fahriani A, Eviyati. 2008. Potensi Rumput Rawa sebagai pakan ruminansia : produksi, daya tampung dan kandungan fraksi seratnya. Jurnal Indonesia Tropik Animal Agriculture. N0 33(4) desember.

Faturrahman. 1988. Analisis Vegetasi dan Produktivitas Rumput Rawa di Kecamatan Danau Panggang Kabupaten Hulu Sungai Utara, Kalimantan Selatan. Karya Ilmiah. Fakultas Peternakan. Institut Pertanian Bogor. Bogor.

Haryuningtyas D, Beriajaya, Gray GD.2001. Resistensi antelmintik golongan benzimidazole pada domba dan kambing di
Indonesia. Seminar Nasional Teknologi Peternakan dan Veteriner, Pusat Penelitian dan Pengembangan Peternakan. Bogor, 17-18 September 2001.

Larsen M. 2000. Prospects for control ing animal parasitic nematodes by predacious micro fungi. Parasitology 120: S121-S131.

Musa AF. 1988. Mengenal Rumput Terapung Daerah Rawa Kalimantan Selatan. Majalah Swadesi Peternakan Indonesia, Edisi Juni 1988. Jakarta.

Rohaeni ES., Darmawan A, Qomariah R, Hamdan A, Subhan A. 2005. Inventarisasi Dan Karakterisasi Kerbau Rawa Sebagai Plasma Nutfah. Laporan Hasil Pengkajian.Balai Pengkajian Teknologi Pertanian (BPTP) Kalimantan Selatan. Banjarbaru.

Steel RGD. Torrie JH. 1993. Prinsip dan Prosedur Statistik. Ed ke-2. Sumantri B, Penerjemah. Jakarta: Gramedia Pustaka Utama. Terjemahan

Suryati T, Astawan M, Wresdiyati T. 2004. Sifat Fisik Daging Domba yang Diberi Perlakuan Stimulasi Listrik Voltase Rendah dan Injeksi Kalsium Klorida. Media Peternakan. 27(3):101-106

Suryati T, Astawan M, Wresdiyati T. 2006. Karakteristik Organoleptik Daging Domba yang Diberi Stimulasi Listrik Voltase Rendah dan Injeksi Kalsium Klorida. Media Pternakan. 29(1):1-6

Urquhart GM., Armour J, Duncan JL, Dunn AM, Jennings FW. 1987. Veterinary Parasitology. Departement of Veterinary Parasitology, Faculty of Veterinary Medicine, The University of Glasgow, Scotland. Longman Scientific \& Technical. Published in USA by Churchill Livingstone Inc, New York.

Waller PJ. 1996. Worm control of livestockthe biological alternative. Workshop on the Sustainable Parasite Control in Small Ruminants, Bogor, Indonesia, 22-25 April 1996. p. $160-164$. 